\title{
Assessment of plant development, morphology and flavonoid content in different cultivation treatments of Calendula officinalis L., Asteraceae
}

\author{
Luis Fernando Nunes Alves Paim, ${ }^{1}$ Marina Fontana, ${ }^{1}$ Marina Winckler, ${ }^{1}$ \\ Adriana Aparecida Grando, ${ }^{1}$ Tânia Lúcia Muneron, ${ }^{1}$ Walter Antônio Roman Júnior ${ }^{*}, 2$
}

\author{
${ }^{1}$ Grupo de Estudos de Plantas Medicinais, Universidade Comunitária da Região de Chapecó, Av. Senador Atílio \\ Fontana 591 E, Caixa Postal 747, 89809-000 Chapecó-SC, Brazil, \\ ${ }^{2}$ Área de Ciências da Saúde, Laboratório de Farmacognosia, Universidade Comunitária da Região de Chapecó, \\ Av. Senador Atílio Fontana 591 E, Caixa Postal 747, 89809-000, Chapecó-SC, Brazil.
}

\begin{abstract}
RESUMO: O objetivo deste estudo foi avaliar a influência dos tratos culturais no desenvolvimento vegetal, morfologia e teor de flavonóides para Calendula officinalis L., Asteraceae. Os tratos culturais foram: calagem (CA), calagem + adubação orgânica (CAO) e calagem + adubação química NPK (CAQ). O experimento foi inteiramente casualizado com sessenta repetições e a comparação das médias realizada por ANOVA e teste de Duncan (significância de 95\%). Os resultados apontam que CAO e CAQ apresentaram maior desenvolvimento vegetal comparados com tratamento CA. O tratamento CAO produziu ainda, plantas com maior homogeneidade, massa fresca e número de capítulos florais por planta, mas menor biomassa de flores produzidas por cada indivíduo. Observou-se também, variações morfoanatômicas com flores tubulares com centro amarelado (TCA) e tubulares com centro acastanhado (TAC) que produziram maior teor de flavonóides (1,41 e 1,44\% respectivamente) comparadas com flores ligulares com centro amarelado (LCA) e ligulares com centro acastanhado (LAC) (0,89 e 0,95\% respectivamente). Os compostos químicos nas flores de calêndula, visualizados por cromatografia em camada delgada, demonstraram que os tratamentos não têm influencia sobre o perfil químico qualitativo do vegetal. Entretanto, cultivares de calêndula submetidas ao tratamento CAQ produziram maior quantidade de flavonóides totais $(1,14 \%)$ contra $1,04 \%$ do CAO e $1,03 \%$ de CA.
\end{abstract}

Unitermos: Calendula officinalis, tratos culturais, desenvolvimento vegetal, teor de flavonóides.

\begin{abstract}
The objective of this study was to examine the influence of cultivation treatments on plant development, morphology and flavonoid content in Calendula officinalis L., Asteraceae. The cultivation treatments were liming (LIM), liming + organic fertilizer (LORG) and liming + NPK chemical fertilizer (LCHEM). The experiment was completely randomized with sixty repetitions and the means were compared by ANOVA and Duncan's test (significance of 95\%). The results show that LORG and LCHEM produced greater plant development compared with LIM treatment. The LORG treatment also produced plants with greater homogeneity, fresh mass, and higher numbers of flowers per plant, but lower biomass of flower produced by each individual. Morphoanatomical variations were also observed with tubular flowers with yellow centres (TCA) and tubular flowers with brown centres (TAC) that produced a higher content of flavonoids (1.41 and $1.44 \%$ respectively), compared with ligulate flowers with yellow centres (LCA) and ligulate flowers with brown centres (LAC) ( 0.89 and $0.95 \%$ respectively). The chemical compounds in the flowers of calendula viewed by thin-layer chromatography showed that the treatments did not have any influence on the qualitative chemical profile of the plant. However, cultivars of calendula that underwent treatment LCHEM produced a greater quantity of total flavonoids (1.14\%) against $1.04 \%$ for LORG and $1.03 \%$ for LIM.
\end{abstract}

Keywords: Calendula officinalis, cultivation treatments, plant development, flavonoid content. 


\section{INTRODUCTION}

Calendula officinalis L. is a herbaceous plant belonging to the family Asteraceae. It is of Mediterranean origin, although the flowers are widely appreciated for their therapeutic properties throughout the world (Chengqi, 2007). Popular knowledge and clinical studies describe numerous biological activities for this plant including antispasmodic, antiinflammatory, anti-septic, wound healing, emollient and sudoriferous effects (Lorenzi \& Matos, 2002). The main phytochemical constituents described in the flowers of this bioactive plant are essential oils $(0.1-0.4 \%)$, triterpene alcohols $(2-5 \%)$ and flavonoids in their free form, isorhamnetin heterosides and quercetin (0.2-0.9\%) (Vanaclocha \& Cañigueral, 2003). Among all the classes of flavonoids present in $C$. officinalis L., the most notable substances are those present in the highest concentrations, quercetin and rutin (Rodrigues et al., 2004).

Originally from Europe and acclimatised to the southern region of Brazil, this plant has been the subject of significant attention on the part of researchers, especially in relation to its commercial cultivation for pharmaceutical and cosmetic ends. On the other hand, there remains a lack of information regarding aspects of agronomics that would lead to greater success with cultivars of this medicinal species (Gazin et al., 2007).

When one intends to cultivate bioactive species for the phytotherapy market, it is necessary to search for information relating to the yield of active principles and morphoanatomical variations, as well as to assess the behaviour of medicinal cultivars, since there are practically no specific programmes of improvement designed to select materials with more uniform genotypic and phenotypic characters (Vieira et al., 2006).

Morphological variability is seen in cultivars of calendula (Calendula officinalis L) with the appearance of plants with flowers of varied size and colouration, compromising the standardisation of the material of interest. This marked variation in plant anatomy allied to the diverse forms of cultivation employed in the field means that the quality and quantity of bioactive products in this plant remain unknown (Bertoni et al., 2006).

Controlling the quality of calendula, from cultivation onwards, becomes an even more difficult task when considering the edaphic and climatic factors such as altitude, temperature, relative humidity of the air, photoperiod, soil, availability of water and nutrients that influence the production of active principles in the plants. Consequently, it is clear that conducting regional studies to examine plant development and the levels of active principles in medicinal species is indispensible with a view to improving the market in phytotherapeutics (MAPA, 2006).

\section{MATERIAL AND METHODS}

\section{General conditions of cultivation}

The experiment was carried out in the plant nursery at Unochapecó (latitude $-27005^{\prime} 47^{\prime \prime}$, longitude $52 \mathrm{O} 37^{\prime} 06^{\prime \prime}$ with an altitude of $674 \mathrm{~m}$ ). The soil used in the experiment was obtained from earth from hillsides in the municipality of Chapecó, Santa Catarina-SC. A soil sample was sent for analysis by the Empresa de Pesquisa Agropecuária e Extensão Rural de Santa Catarina for adjustment of the $\mathrm{pH}$. Calendula seeds were obtained from the commercial source Agristar ${ }^{\circledR}$ do Brasil Ltda. The seeds were of the species Calendula officinalis, a new cultivar, with a purity of $99.1 \%$ and a germination index of $64 \%$ according to the data provided by the supplier. They were seeded in plastic tubettes containing organic substrate. Two seeds were placed in each one of the tubettes at a depth of $2 \mathrm{~cm}$. Following germination the individuals were maintained in a germination house for exactly 30 days, at a controlled temperature of $22 \pm 1{ }^{\circ} \mathrm{C}$ maintained by an air conditioning system, with a relative humidity above $90 \%$ and a light/dark period of $12 / 12 \mathrm{~h}$, which was maintained by fluorescent bulbs (Acosta Da Luz et al., 2001). Next, the seedlings were transferred in their tubettes from the germination house to an external area covered with Sombrite ${ }^{\circledR}$. They were kept in this space for 25 days until they had reached the ideal stage of development for transplantation. In the final stage the experiment was carried out in black plastic bags, with a capacity for $3.5 \mathrm{~kg}$ of earth previously sieved through a $4 \mathrm{~mm}$ mesh (Moreira et al., 2005); this stage commenced when the seedlings had grown to approximately $10 \mathrm{~cm}$ in height and had developed six leaves (Vieira et al., 2006). These individuals were positioned randomly in the cultivation area in 36 rows of five plants at a distance of $0.35 \mathrm{~m}$ from each other and in five columns $0.20 \mathrm{~m}$ apart (Vieira et al., 2006). The plants were left in the same position throughout the duration of the experiment and were watered on alternate days by means of an automatic drip irrigation system. The treatments applied were: Liming (LIM) (pH 5.5); Liming + Organic Fertiliser (LORG) (pH $5.5+$ Organic plant compost 60 tonnes $\mathrm{x}$ hectare-1) and Liming + Chemical Fertiliser (LCHEM) (pH 5.5 + NPK in the proportion 80/120/80 kg $\mathrm{x}$ hectare ${ }^{-1}$ ) with each treatment group consisting of sixty individuals. The doses necessary to correct the $\mathrm{pH}$ for all treatments (LIM, LORG and LCHEM) and the quantity of chemical fertilisers to be incorporated in the LCHEM treatment were calculated taking into account the results of the soil analysis performed previously. The dose of organic fertiliser in treatment LORG was calculated from data in the literature for the cultivation of this plant. The dose of non-residual organic fertiliser, recommended for quantitative (number of heads $\mathrm{x} \mathrm{plant}^{-1}$ ) and qualitative production (amount of total flavonoids) of calendula is 6 
$\mathrm{kg} / \mathrm{m}^{2}$ (Leite et al., 2005).

The dose of fertiliser to be added to each 3.5

$\mathrm{kg}$ plastic bag was calculated taking into account the quantity required for 1 hectare $\left(=10,000 \mathrm{~m}^{2}\right)$ with a depth of $0.2 \mathrm{~m}(2,000,000 \mathrm{~kg}$ of earth).

Determination of vegetative development in the individuals

The vegetative development of individual plants was determined at regular intervals of 15 days and measured by the height in centimetres from the level of implantation in the soil to the apex of all the individual plants for all the treatments (Moreira et al., 2005).

Determination of the development of the individuals (mean weight in the ratio weight in $\mathrm{kg} / \mathrm{height}$ in metres $^{2}$ )

The development of the individuals was measured by collecting all the plants from all the treatments on the $95^{\text {th }}$ day of development. The plants were cut whole from the level of the soil and weighed on a precision balance. A ratio between the weight and the height of the plants given by the formula (weight in $\mathrm{kg} /$ height in metres $^{2}$ ) was employed to test the influence of the treatments on the plant profiles (Moreira et al., 2005).

\section{Morphoanatomical variations in the flowers across} the total population

The morphoanatomical variations in the flowers across the total population and treatments tested were analysed by taking as a reference the morphological description of the flowers from the Portuguese Pharmacopeia (1997). The flower heads were classified according to their morphology as ligulate and tubular, and also with regard to the coloration of the centre of the flower, classifying them as yellow or brown. The possible combinations were: plants with ligulate flowers with a brown centre (LBC); plants with tubular flowers with a brown centre (TBC); plants with ligulate flowers with a yellow centre (LYC); and plants with tubular flowers with a yellow centre (TYC).

Mean number of flowers, mean weight and biomass of material of interest

The flowers were collected manually at regular intervals of 7 days. Flowering began on the $45^{\text {th }}$ day after transfer of the individuals to the cultivation area. The flowers from all the individuals in the experiment were collected. The flower heads were collected when the petals were found in a horizontal position (Vieira et al., 2006). The biomass of material of interest (dried ligulate florets and composite flowers) produced by the individuals was quantified by multiplying the number of flowers by the mean weight of the flowers produced.

\section{Thin layer chromatography (TLC) and concentration of flavonoids}

The chromatographic profile was obtained by developing the plate in a methanolic solution of 5\% sulphuric acid (v/v) followed by $1 \%$ sulphuric vanillin $(\mathrm{v} / \mathrm{v})$. Next, the plate was transferred to an incubator, previously heated to $110^{\circ} \mathrm{C}$, for $5 \mathrm{~min}$. The quantification of flavonoids was carried out in triplicate $(\mathrm{n}=3)$ by means of the UV/Vis spectroscopic method with a wavelength of $425 \mathrm{~nm}$. Both methods were performed according to the monograph for calendula in the Brazilian Pharmacopeia (1996).

\section{Statistical treatment}

The experimental design adopted in the assays was entirely randomised. The effect of treatments LIM, LORG and LCHEM on plant development and the levels of flavonoids was determined by one-way analysis of variance (ANOVA), followed by multiple comparison (Duncan's Test). The results were expressed as mean \pm standard error of the mean.

\section{RESULTS AND DISCUSSION}

\section{Plant development}

Vegetative development in medicinal species is described in the literature as one of the factors that can interfere with the amounts of active principles produced by a given species (Moreira et al., 2005). The adoption of cultivation treatments, as well as fertilisers, is an indication that the species can produce greater quantities of active principles, considering that many nutrients contained in the fertiliser are found to be involved in secondary metabolic pathways (Taiz \& Zeiger, 1991). In this work, analysis of the soil used in the experiment (Table 1) served as a parameter for the establishment of the quantities of fertilisers required for the development of the calendula plants: these compounds were added based on the results of the analysis and we sought to determine their influence over the development of the plants.

It can be seen that the vegetative development exhibited significant differences as a result of the treatments tested. Table 2 presents the mean heights of the plants over the course of the experimental period. 
Table 1. Result of the analysis carried out by Epagri of the soil used in the experiment in Chapecó.

\begin{tabular}{|c|c|c|c|}
\hline Parameter & Result & Parameter & Result \\
\hline$\%$ Clay $\mathrm{m} / \mathrm{V}$ & 62 & $\mathrm{H}+\mathrm{Al} \mathrm{cmoc} / \mathrm{dm}^{3}$ & 6.90 \\
\hline $\mathrm{pH}$ - Water 1:1 & 4.40 & $\mathrm{CTC} \mathrm{cmoc} / \mathrm{dm}^{3}$ & 7.27 \\
\hline SMP Index & 5.60 & $\begin{array}{c}\text { \% Saturation CTC } \\
\text { bases }\end{array}$ & 5.04 \\
\hline $\mathrm{P} \mathrm{mg} / \mathrm{dm}^{3}$ & 3.50 & $\begin{array}{c}\text { \% Saturation CTC } \\
\mathrm{Al}\end{array}$ & 85.14 \\
\hline $\mathrm{K} \mathrm{mg} / \mathrm{dm}^{3}$ & 26 & $\begin{array}{c}\mathrm{Lim} / \mathrm{Mg} \\
\text { Relationship }\end{array}$ & 0.50 \\
\hline$\% \mathrm{M} . \mathrm{O} \mathrm{m} / \mathrm{v}$ & 0.80 & Lim/K Relationship & 1.50 \\
\hline $\mathrm{Al} \mathrm{cmoc} / \mathrm{dm}^{3}$ & 2.10 & $\mathrm{Mg} / \mathrm{K}$ Relationship & 3.01 \\
\hline Lim $\mathrm{cmoc} / \mathrm{dm}^{3}$ & 0.10 & $\mathrm{Mg} \mathrm{cmoc} / \mathrm{dm}^{3}$ & 0.20 \\
\hline $\mathrm{Mg} \mathrm{cmoc} / \mathrm{dm}^{3}$ & 0.20 & & \\
\hline
\end{tabular}

Despite the fact that calendula exhibits hardiness and adapts well to soils that are relatively poor in organic material, the employment of the latter can increase vegetative development in this species (Acosta Da Luz et al., 2001). In general terms, organic fertiliser releases nutrients to the plants more slowly and in a more constant manner, bringing benefits of a chemical and physical nature to the soil. The organic material brings about improvements to soil structure, aeration, drainage and water retention (Sedrez dos Reis \& Mariott, 1999). It can be suggested that this fact contributed to the better development of the plants submitted to LORG treatment when compared to the LIM treatment.

The mean number of flowers produced by the plants was found to be higher with the LORG treatment; on the other hand, the flowers obtained with LIM treatment were found to be larger. It should be noted that on multiplying the variables mean number of flowers $x$ mean weight of the flowers, the effect of the treatments on the biomass of flowers was found to be not significantly different between the different treatments (Table 3). On the other hand, treatments LORG and LCHEM increased the mean weight of the plants at 95 days of development, resulting in plants with a greater mean weight than that observed with the treatment involving LIM.

The flowers constitute the plant material of pharmaceutical interest for the species Calendula officinalis. In Brazil, the inflorescences of calendula are found with numerous colorations including yellow, orange, and green with a yellow or brown centre (Vieira et al., 2006). These morphological variations are highlighted in pharmacopoeia monographs for calendula. For example, in the Portuguese Pharmacopeia (1997), among the characteristics described for the material of interst is the presence of ligulate and tubular flowers in the constitution of the plant. According to Oliveira \& Akisue (2000), ligulate and tubular flowers are frequent in the family Asteraceae (Compositae) of which calendula is a member. Ligulate flowers are characterised by the presence of fused petals forming a kind of tongue, while the tubular flowers are fused to form a kind of tube; generally the latter present teeth in the upper part. The different types of flowers produced by individuals of calendula in this study are shown in Figures 1, 2, 3 and 4. It is important to note that in the data sheet provided with the seeds the supplier describes the product as Calendula officinalis new cultivar, with a purity of $99.1 \%$. As a result it can be inferred that the morphoanatomical variations are present even in cultivars of calendula intended for the commercial production of seeds, a fact which compromises the quality control of products obtained from the plant species. Besides the variation in colouration, variations in size have also been described, and these factors have been indicated to be major impediments to the success of calendula cultivars (Bertoni et al., 2006).

Table 2. Mean heights in millimetres $(\mathrm{mm})$ of plants cultivated at Chapecó. The values expressed represent the means \pm standard error of the mean (SEM); means in the same column followed by different letters differed significantly $(p<0.05)$ from each other.

\begin{tabular}{lcccc}
\hline \multicolumn{1}{c}{ Treatment } & At 15 days & At 30 days & At 45 days & At 95 days \\
\hline Liming (LIM) & $114.9 \pm 30.3 \mathrm{~mm} \mathrm{(a)}$ & $140.8 \pm 36.3 \mathrm{~mm} \mathrm{(a)}$ & $170.0 \pm 60.4 \mathrm{~mm}$ (a) & $373.2 \pm 128.9 \mathrm{~mm}$ (a) \\
Liming + Organic Fertiliser (LORG) & $131.8 \pm 22.5 \mathrm{~mm} \mathrm{(b)}$ & $155.8 \pm 22.6 \mathrm{~mm} \mathrm{(b)}$ & $213.0 \pm 60.7 \mathrm{~mm} \mathrm{(b)}$ & $441.0 \pm 116.7 \mathrm{~mm}$ (b) \\
Liming + Chemical Fertiliser (LCHEM) & $110.4 \pm 33.1 \mathrm{~mm} \mathrm{(a)}$ & $143.1 \pm 32.1 \mathrm{~mm} \mathrm{(a)}$ & $188.8 \pm 68.1 \mathrm{~mm}$ (a) & $419.7 \pm 122.2 \mathrm{~mm}$ (b) \\
\hline
\end{tabular}

Table 3. Development of cultivars of calendula in the experimental plot at Unochapecó (Chapecó-SC). The values expressed represent the means \pm standard error of the mean (SEM); means in the same column followed by different letters differed significantly $(p<0.05)$ from each other.

\begin{tabular}{|c|c|c|c|c|c|}
\hline Treatment & $\begin{array}{c}\text { Mean number of } \\
\text { flowers }\end{array}$ & $\begin{array}{c}\text { Mean weight of } \\
\text { flowers }\end{array}$ & Biomass of flowers & $\begin{array}{l}\text { Mean plant weight } \\
95 \text { days }\end{array}$ & Ratio \\
\hline Liming (LIM) & $3.6 \pm 1.87$ (a) & $1.50 \pm 0.88 \mathrm{~g}(\mathrm{c})$ & $5.40 \pm 2.80 \mathrm{~g} \mathrm{(a)}$ & $24.8 \pm 14.00 \mathrm{~g} \mathrm{(a)}$ & $0.23 \pm 0.19 \mathrm{~g}(\mathrm{a})$ \\
\hline Liming + Chemical Fertiliser (LCHEM) & $4.0 \pm 2.64(\mathrm{a})$ & $1.37 \pm 0.69 \mathrm{~g}(\mathrm{~b})$ & $5.48 \pm 3.60 \mathrm{~g} \mathrm{(a)}$ & $33.3 \pm 16.73 \mathrm{~g}(\mathrm{~b})$ & $0.22 \pm 0.15 \mathrm{~g} \mathrm{(a)}$ \\
\hline
\end{tabular}




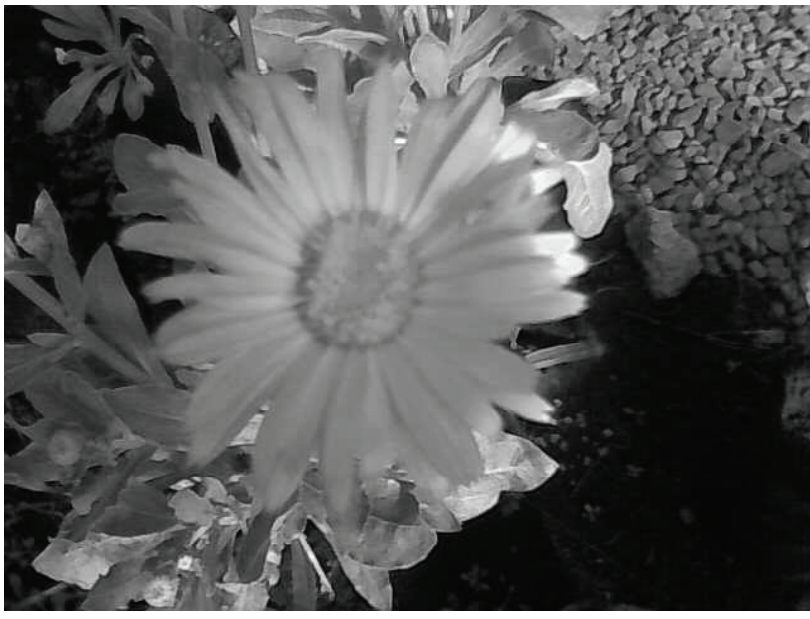

Figure 1. Calendula flower of the ligulate shape with a yellow centre (LYC), cultivated in the experimental plot at Unochapecó (Chapecó-SC).

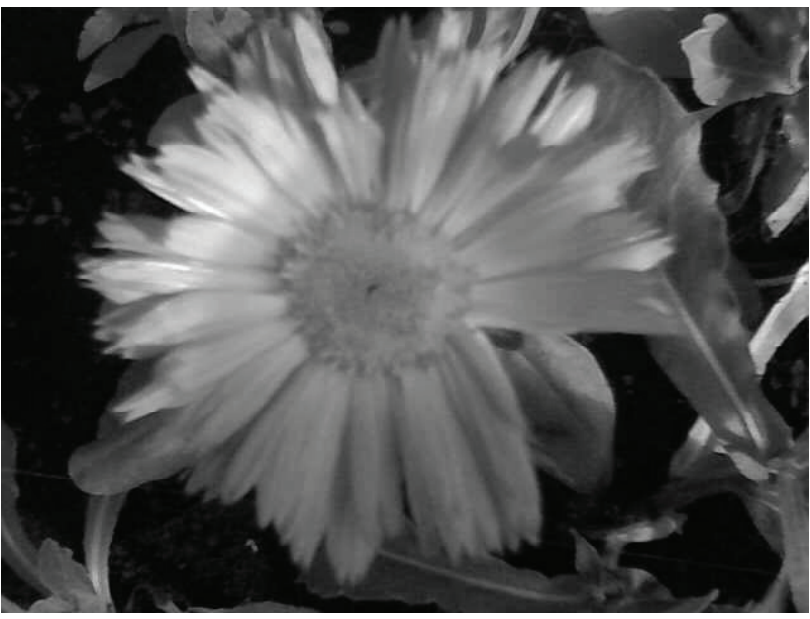

Figure 3. Calendula flower of the tubular shape with a yellow centre (TYC), cultivated in the experimental plot at Unochapecó (Chapecó-SC).

Figure 5 shows the frequency with which each morphoanatomical variant appeared in the population of plants studied. There was a notable predominance of individuals with ligulate flowers $(\mathrm{LBC}+\mathrm{LYC}=73 \%$ ) over those with tubular flowers $(\mathrm{TYC}+\mathrm{TBC}=19 \%)$. Silva Júnior (2003) reported a large variation in the genotypes of calendula reported in the literature, which even extended to the profile of secondary metabolites of the plant. According to Armond (1998), the folded (tubular) cultivars with petals in darker shades are the most highly recommended in pharmacopeia monographs for the plant. The lower percentage of individuals with tubular flowers observed in our study signals the importance of the selection and multiplication of such individuals, with this being an important instrument to maximise the production of secondary metabolites which, consequently, would contribute to improving the final quality of the products obtained from calendula.

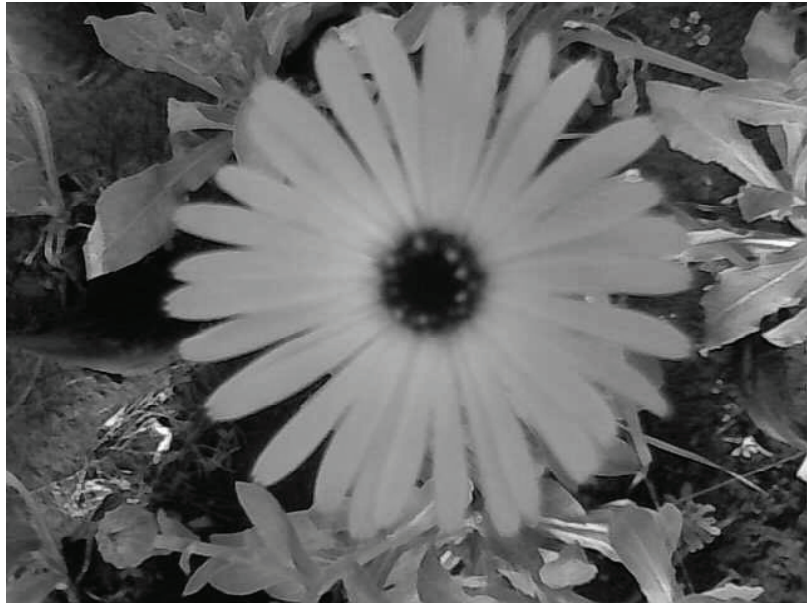

Figure 2. Calendula flower of the ligulate shape with a brown centre (LBC), cultivated in the experimental plot at Unochapecó (Chapecó-SC).

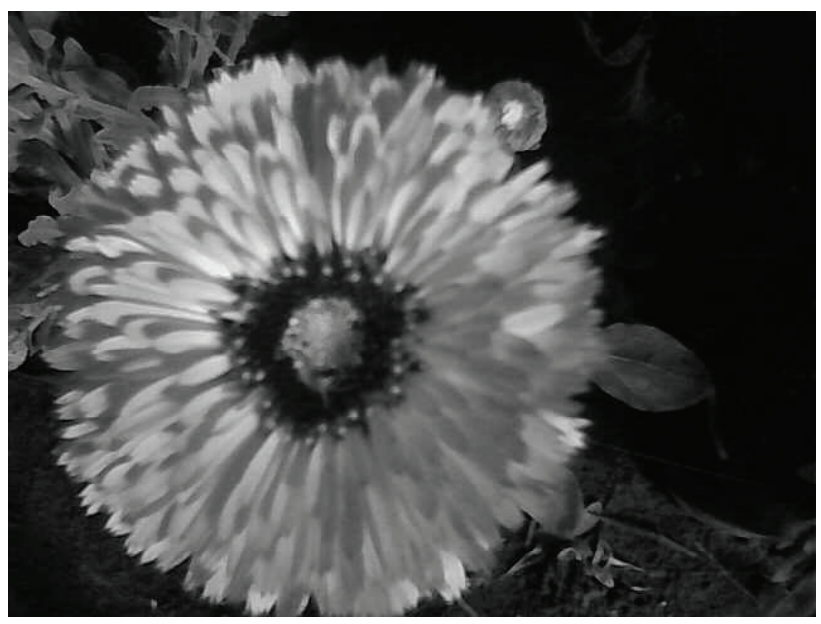

Figure 4. Calendula flower of the tubular shape with a brown centre (TCA), cultivated in the experimental plot at UNochapecó (Chapecó-SC).

The result of the chromatographic profile (Figure 6) obtained for the different treatments indicates that in qualitative terms there were differences in the chemical constituents of calendula with the different treatments. The chromatogram was developed according to the Brazilian Pharmacopeia (1996).

In relation to the quantification of flavonoids (Figure 7) it can be seen that the LCHEM treatment raised the quantity of total flavonoids by around $10 \%$ when compared to LIM and LORG treatments. This result contradicts the belief that certain plants produce greater amounts of active substances when they are subjected to conditions of stress, in this case a lack of macronutrients and organic material in the plant species calendula. The active principle of interest is associated with the secondary metabolism of the plant, which reflects specific adaptations to adverse conditions or to defence mechanisms, and such pathways may be stimulated by exposure of the plant, for 
example, to a nutrient-rich environment (Sedrez dos Reis \& Mariott, 1999).

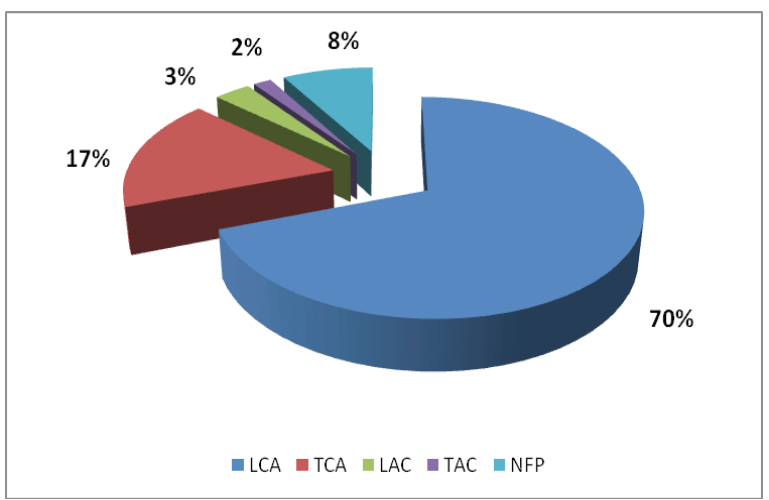

Figure 5. Percentage of each morphoanatomical variant of calendula cultivated in Chapecó: LBC (Ligulate with Brown Centre)(70\%); TBC (Tubular with Brown Centre) (17\%); LYC (Ligulate with Yellow Centre) (3\%); TYC (Tubular with Yellow Centre) (2\%); DNF (Did not flower/died) (8\%).

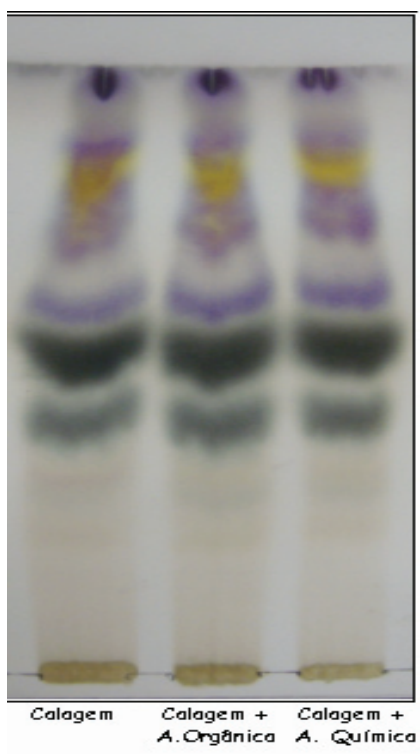

Figure 6. Chromatographic profiles of the flowers of calendula subjected to different treatments. Stationary phase: silica gel $\left(\mathrm{FG}_{254}\right)$. Mobile phase: Merck $^{\circledR}$ mixture of anhydrous formic acid:glacial acetic acid:water:ethyl acetate (11:11:27:100 v/v), methanolic solution of $5 \%$ sulphuric acid $(\mathrm{v} / \mathrm{v})$ followed by $1 \%$ sulphuric vanillin $(\mathrm{v} / \mathrm{v})$.

Quantitative variation in the chemical constituents due to specific characteristics of the morphological variants among individuals of a single plant species has been previously described in the literature for some medicinal species (Silva Junior, 2003). In the case of calendula there is evidence that individuals with orange petals are the richest in secondary metabolites (Silva Junior, 2003). In this work we observed that those variants with tubular flowers had a higher flavonoid content, as a percentage, than those with ligulate flowers. Figure 8 shows the percentage levels expressed as hyperoside $\left(\mathrm{C}_{21} \mathrm{H}_{20} \mathrm{O}_{12}\right)$.

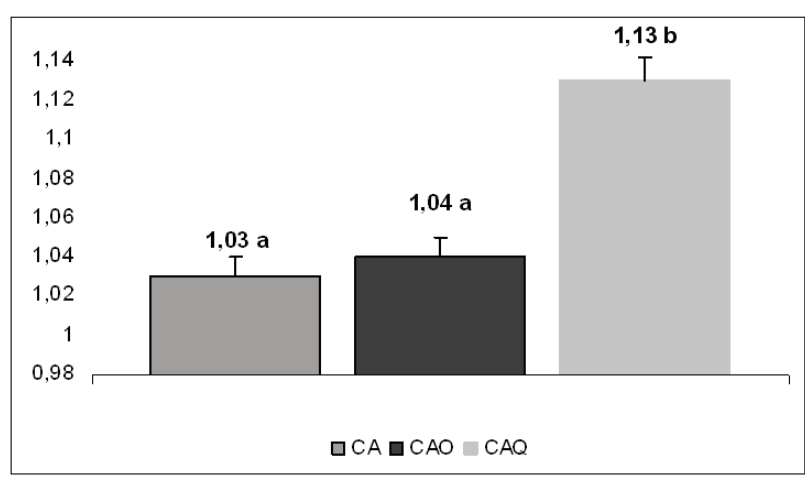

Figure 7. Percentage of total flavonoids in calendula cultivated in Chapecó, by treatment tested. Means followed by the same letters were not significantly different from each other according to Duncan's test; $p<0.05$.

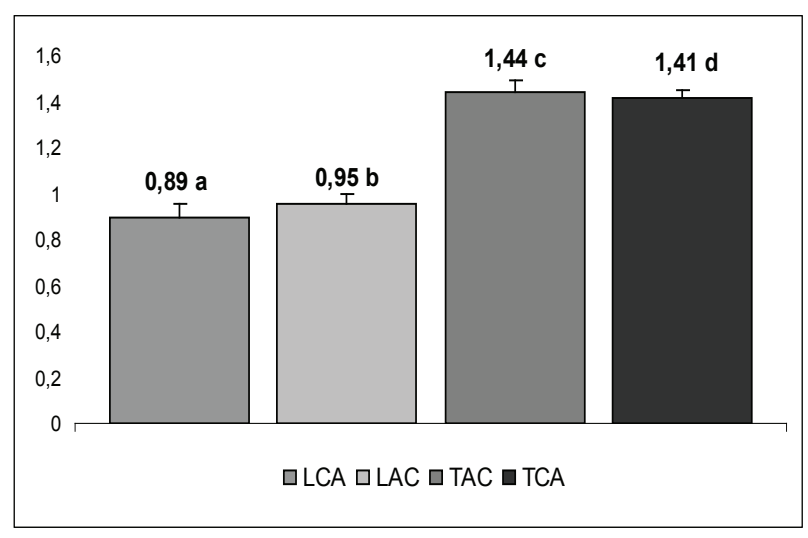

Figure 8. Percentage of total flavonoids in calendula cultivated in Chapecó, by morphoanatomical variant. Means followed by the same letters were not significantly different from each other according to Duncan's test; $p<0.05$.

\section{CONCLUSION}

The results of this investigation suggest that the LORG treatment was able to increase the vegetative development of the medicinal species calendula during the first 45 days of development. After 95 days treatments LORG and LCHEM produced similar results to each other with regard to the vegetative development of the plant, demonstrating that for this plant cultivation treatments such as the addition of organic and chemical fertiliser improve the development of the plant, when compared to the control without fertiliser.

The LORG treatment resulted in plants with greater homogeneity in height than with the other treatments tested, something that would facilitate the process of mechanisation of flower harvest. This finding is very relevant, since one of the inconvenient aspects of medicinal cultivars is the lack of standardisation in the size of the individuals, which results in an increase in labour and, consequently, in the cost of the raw materials produced.

In addition, the plants subjected to the LORG 
treatment presented the best vegetative development (fresh mass) compared to the other treatments tested. On the other hand, there were no significant differences in the weight:height ratio, with this being determined by the genotype. LORG treatment also increased the number of flower heads per plant, but not the biomass of flowers produced by each individual. Thus, in the process of obtaining the material of interest of calendula (inflorescences) no significant difference was observed between the treatments tested.

In this experimental cultivation morphoanatomical variations of calendula were observed. Plants were obtained that had tubular flowers with a yellow centre (TYC), and tubular flowers with a brown centre (TBC), which produced higher levels of flavonoids (1.41 and $1.44 \%$ respectively), when compared to ligulate flowers with a yellow centre (LYC) and ligulate flowers with a brown centre (LBC) ( 0.89 and $0.95 \%$ respectively). Among the plants examined $79 \%$ of the individuals presented ligulate flowers with a brown centre; on the other hand, the measurement of flavonoid concentrations demonstrated that the flavonoid percentages in this type of flower were the lowest among the four variants at $0.89 \%$. These results indicate the requirement for further research in the area of plant biotechnology to obtain selected explants with elevated levels of flavonoids.

The chemical compounds present in the flowers of calendula visualised by TLC demonstrate that the treatments tested did not influence the qualitative profile of chemical substances present in the plants. Nevertheless, the cultivars of calendula subjected to LCHEM treatment produced greater quantities of total flavonoids compared to the other treatments. It is supposed that the nitrogen present in LCHEM may be related to this phenomenon, given that this nutrient participates in the flavonoid biosynthetic pathway.

\section{REFERENCES}

Acosta da Luz L, Ferrada CR, Govin ES 2001. Instrutivo técnico de Calendula officinalis. Rev Cubana Plant Med 23: 2327.

Armond C 1998. Produção e teor de óleos essenciais da Calêndula (Calendula officinalis L.) cultivada em compostos orgânicos de diferentes resíduos. Viçosa: Editora UFV.

Bertoni BW, Damião Filho CF, Moro JR, França SC, Pereira AMS 2006. Micropropagação de Calendula officinalis L. Rev Bras Pl Med 8: 48-54.

Chengqi A 2007. Comparative anatomy of bisexual and female florets, embryology in Calendula officinalis (Asteraceae), a naturalized horticultural plant. Scientia Horticulturae 114: 214-219.

Farmacopeia Brasileira 1996. 4. ed. São Paulo: Atheneu.

Farmacopeia Portuguesa 1997. VII ed. Lisboa: Infarmed.

Gazin ZC, Ferreira GA, Rezende CM, Nakamura CV, Dias Filho BP, Cortez DAG 2007. Identificação dos constituintes químicos da fração volátil da Calendula officinalis produzida no Paraná. Hortic Bras 25: 118-121.
Leite GLD, Araújo CBO, Amorim CAD, Pego AP, Martins ER, Santos EAM 2005. Níveis de adubação orgânica na produção de calêndula e artrópodes associados. Arq Inst Biol 72: 227-233.

Lorenzi H, Matos FJA 2002. Plantas medicinais no Brasil: nativas e exóticas. São Paulo: Instituto Plantarum de Estudos da Flora.

Ministério da Agricultura Pecuária e Abastecimento 2006. Plantas medicinais: Orientações Gerais para o cultivo. Brasília: MAPA/SDC.

Moreira PA, Marquechi ME, Vieira MC, Novelino JO, Gonçalves MC, Robaina AD 2005. Desenvolvimento vegetativo e teor foliar de macronutrientes da calêndula (Calendula officinalis L.) adubada com nitrogênio e fósforo. Rev Bras Pl Med 8: 18-23.

Oliveira F, Akisue MK 2000. Farmacognosia. São Paulo: Atheneu.

Rodrigues PO, Gonçalves TC, Silva WB 2004. Influência de diferentes solventes no processo de extração de Calêndula officinalis L (Asteraceae). Lat Am J Pharm 23: 27-31.

Sedrez dos Reis M, Marriot A 2000. Diversidade natural e aspectos agronômicos de plantas medicinais. In: Simões CMO, Schenkel EP, Gosmann G, Mello JCP, Mentz LA, Petrovick PR (eds.) Farmacognosia: da planta ao medicamento. Porto Alegre/Florianópolis: UFRGS/ UFSV, 2000.

Silva Jr AA 2003. Essentia herba: Plantas bioativas. Itajaí: Epagri.

Taiz L, Zeiger E 1991. Plant physiology. California: The Benjamin/Cummings Publishings Company.

Vanaclocha B, Cañigueral S 2003. Fitoterapia. Vademecum de presscripcion. Barcelona: 4 ed. Masson.

Vieira MC, Gomes HE, Sangalli A, Heredia ZNA, Teixeira IR, Ramos MBM 2006. Crescimento e produção de biomassa 